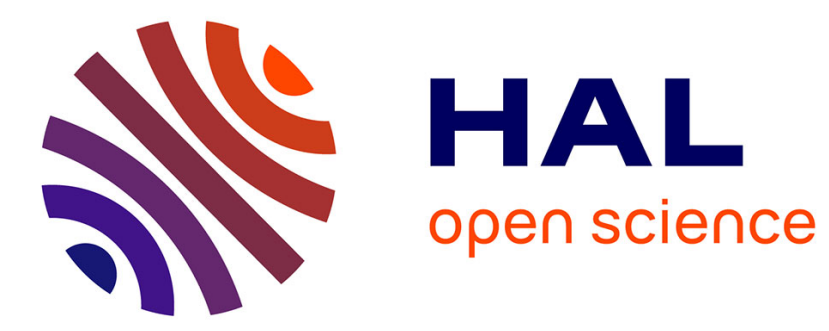

\title{
Policing, young people, diversion and accountability in Ireland
}

\author{
Ursula Kilkelly
}

\section{To cite this version:}

Ursula Kilkelly. Policing, young people, diversion and accountability in Ireland. Crime, Law and Social Change, 2011, 55 (2-3), pp.133-151. 10.1007/s10611-011-9275-8 . hal-00676223

\section{HAL Id: hal-00676223 \\ https://hal.science/hal-00676223}

Submitted on 4 Mar 2012

HAL is a multi-disciplinary open access archive for the deposit and dissemination of scientific research documents, whether they are published or not. The documents may come from teaching and research institutions in France or abroad, or from public or private research centers.
L'archive ouverte pluridisciplinaire HAL, est destinée au dépôt et à la diffusion de documents scientifiques de niveau recherche, publiés ou non, émanant des établissements d'enseignement et de recherche français ou étrangers, des laboratoires publics ou privés. 


\title{
Policing, Young People, Diversion and Accountability in Ireland
}

\author{
Ursula Kilkelly*
}

\begin{abstract}
The Irish police practice of diverting young offenders was placed within a statutory framework in 2001. The police discretion in the management of young offenders that had been a feature of the administrative process was retained at the heart of the new statutory programme although attempts were made to streamline the process. This article critiques the law, policy and practice underpinning the exercise of that discretion against the relevant international human rights standards on transparency, accountability and professionalism in juvenile justice. It reveals how the management of the programme in practice falls short of these standards and, in particular, the due process rights of the children who come within its reach. It argues that the root of the problem lies primarily in the lack of published criteria to guide the discretionary decision-making at several stages of the programme, and the lack of a credible complaint or review mechanism for the children affected. It recommends the publication of reasons for decisions taken in the exercise of Garda discretion in individual cases, together with provision for review or appeal of such decisions as well as regular independent monitoring of the operation of the programme as a whole.
\end{abstract}

\section{Introduction}

The police play a key role in youth justice. Whether apprehending and questioning suspects or interfacing with young people in their communities, police frequently present the first point of contact that young people have with the criminal justice system, and with the law in general [32]. In these interactions, which frequently take place on the street and in conditions of low visibility, the authority of the police officer is heightened by the relative powerlessness and vulnerability of the young person. In formal terms, any decision the police officer takes - to issue instructions, to question, to refer him/her for diversion or to charge the young person - will impact on the young person, sometimes with long-term consequences. More informally, the nature of this contact between young people and the police can be pivotal in the cultivation of the attitudes that young people develop towards the police, which they then carry into adulthood, sometimes with inter-generational consequences. Research 
shows that police legitimacy in the eyes of young people is derived at least in part from the manner in which they treat young people in their communities. In this way, the adherence of police work to values of due process and accountability is critical to the acceptance of police by young people as well as to the observance of international human rights obligations. These factors make it imperative that engagement between young people and the police is characterised by checks and balances that ensure respect for the rights of young people and accountability for the way they are treated.

The Garda (Police) Diversion Programme, which aims to divert children from further offending and from court, is a formalised system of intervention between young people and police. The scope and scale of the Programme means that it is a highly visible and important barometer of the relationship between young people and the police in Ireland. ${ }^{1}$ Accordingly, it is an important vehicle through which the values of respect and accountability can be delivered. The aim of this paper is to consider the extent to which the Diversion Programme reflects these values in law, policy and practice. It also aims to explore how the Programme's performance can be enhanced in raising the legitimacy of the police in the eyes of young people. The paper is divided into five parts. Part 1 outlines the international standards and research on youth justice and accountability with particular regard to policing. Part 2 considers the law and policy framework that governs the treatment of young people by the police in Ireland. Part 3 of the paper analyses the operation of the Diversion Programme with reference to the available data, while Part 4 considers the due process and accountability questions that arise from this analysis. The final Part considers the question of complaints and monitoring and the paper finishes with some recommendations on what needs to be done to promote greater adherence to the requirement of accountability in the Programme. ${ }^{2}$

\section{International Standards and Research}

A broad range of authorities inform our understanding of best practice in police work with young people. In general terms, Article 40 of the United Nations Convention on the Rights of the Child (CRC), ratified by Ireland in 1991, makes express provision for the rights of

\footnotetext{
Senior Lecturer in Law, School of Law, University College Cork

${ }^{1}$ Every young person is referred to the Programme at their first offence; meaning that approximately 25,000 young people come into contact with it every year.

${ }^{2}$ The treatment of children during questioning and at police stations is beyond the scope of this paper. For a comprehensive analysis of the law see [30; pp.46-69; 19; pp.100-122].
} 
children in youth justice. ${ }^{3}$ In particular, the CRC provides for the right of the child in conflict with the law to be treated

in a manner consistent with the promotion of the child's sense of dignity and worth, which reinforces the child's respect for the human rights and fundamental freedoms of others and which takes into account the child's age and the desirability of promoting the child's reintegration and the child's assuming a constructive role in society [27; art.40(1)].

To this end, Article 40 details the minimum guarantees to which children are entitled in the criminal process including the right to have the matter determined without delay by a competent, independent and impartial authority in a fair hearing according to law. Article $40(3)$ is especially relevant to the relationship between young people and the police insofar as it requires states 'to seek to promote the establishment of laws, procedures, authorities and institutions specifically applicable to children alleged as, accused of, or recognized as having infringed the penal law.' As a particular illustration of this, the CRC requires that whenever appropriate and desirable, measures must be adopted to deal with such children "without resorting to judicial proceedings, providing that human rights and legal safeguards are fully respected' [27; art.40(3)]. The Committee on the Rights of the Child, which has responsibility for monitoring implementation of the $\mathrm{CRC}$, has noted the benefits to children and to society of alternatives to judicial procedures [10; para.5], but has warned that the 'utmost care' must be taken to ensure that the child's human rights and legal safeguards are fully respected and protected in such matters [10; paras.22 and 26]. Moreover, the Committee has explained that 'diversion' should be used only when there is

compelling evidence that the child committed the alleged offence, that he/she freely and voluntarily admits responsibility, and that no intimidation or pressure has been used to get that admission and, finally, that the admission will not be used against him/her in any subsequent legal proceeding.' [10; para.27]

The child's consent must also be based on adequate and specific information on the nature, content and duration of the measure, and on the consequences of a failure to cooperate, carry out and complete the measure [28; r.3].

It is recommended that the relevant law contain specific provisions indicating in which cases diversion is possible, and that the powers of the police, prosecutors and/or other agencies to make decisions in this regard should be regulated and reviewed. The Committee has stipulated that the child must be given the opportunity to seek legal or other appropriate

\footnotetext{
${ }^{3}$ The Convention defines a child as every human being below the age of 18 years unless under the law majority is attained earlier [27; art.1].
} 
assistance on the appropriateness and desirability of the diversion offered by the competent authorities, and on the possibility of review of the measure. It has also recommended that the completion of the diversion by the child should result in a definite and final closure of the case. Accordingly, although confidential records of diversion may be kept for administrative and review purposes, they should not be viewed as 'criminal records' and a child who has been previously diverted must thus not be seen as having a previous conviction [28; r.3].

Discretion is a core principle of police work and it is important to ensure that the implementation of any sanctions or measures is adapted to the particular circumstances of each case [13; para.6]. According to the Standard Minimum Rules on the Administration of Juvenile Justice (the Beijing Rules) [28], the availability of discretion at all stages of the justice process is justified by the varying special needs of juveniles as well as the variety of measures available [28; r.6]. Equally, as the international standards make clear, the exercise of this discretion must be subject to clearly defined limits and remedies must be available to those seeking to challenge the way in which the discretion has been used. To this end, the Beijing Rules recommend that discretion be exercised in accordance with criteria set down by law and they require the provision of sufficient accountability at all stages and levels in the exercise of any such discretion [28; r.6]. The Rules note that accountability and professionalism are the instruments most suitable to curb broad discretion. They advocate that those who exercise discretion are specially trained to do so judiciously and in accordance with their functions and mandates $\left[28 ;\right.$ r.6]. ${ }^{4}$ The importance of police professionalism in this context is emphasized by the Committee on the Rights of the Child, which stipulates that a comprehensive juvenile justice system requires both the establishment of specialized units within the police (among others) [10; para.92] and specialist training for all those involved in law enforcement in juvenile justice [10; para.97].

Accountability is especially important in the context of police decision-making based on discretion rather than, or in addition to, transparent and objective criteria. Where sanctions and measures are imposed on young people by a body other than a court, they should be subject to judicial review [13; para.3]. In general, the Committee on the Rights of the Child has urged states to ensure that children treated unfairly should have the right to access an independent complaint mechanism, which provides redress and compensation [10; para.7, 8;

\footnotetext{
${ }^{4}$ See also, the Commentary to the Rules.
} 
para.24]. More specifically, international standards require that children and their guardians have ample opportunity to make requests or complaints to the authority responsible for any measures to which children are subject and these procedures must be simple and effective [13; para.122-122.1]. Any denial of such a request should be accompanied by reasons and should be subject to an independent appeal procedure [13; paras.122.3 and 122.4]. Building an impartial system of review or appeal into decision making that affects children enhances the integrity of the decision-making process. This is especially important where the process may appear to lack transparency. Overall, the standards require that the administration of any sanctions on young people be subject to regular independent monitoring [13; para.20].

Research has highlighted risks associated with early intervention measures which lead to more intensive intervention with increasingly punitive tendencies [15]. Indeed, recent research suggests that the deeper the child's involvement in the system the more likely he/she is to re-offend [23]. It would appear that keeping children out of the system altogether may be the most effective intervention in certain cases. This perspective is reflected in the international standards which note that, notwithstanding the benefits of diversion, nonintervention is itself a legitimate response in certain cases [28; r.11]. ${ }^{5}$ For example, the Beijing Rules advocate dealing with children without referring them to alternative (social) services especially where the offence is of a 'non-serious nature' and 'where the family, the school or other informal social control institutions have already reacted, or are likely to react, in an appropriate and constructive manner' [28]. This theme is also reflected strongly in the United Nations Guidelines for the Prevention of Juvenile Delinquency (the Riyadh Guidelines), which stress that '[f]ormal agencies of social control should only be utilised as a means of last resort' [29; para.6]. The Guidelines also note that in adopting progressive policies and programmes to respond to and prevent juvenile delinquency, consideration should be given to the fact that

'youthful behaviour or conduct that does not conform to overall social norms and values is often part of the maturation and growth process and tends to disappear spontaneously in most individuals with the transition to adulthood' [29; para.5(e)].

As explained above, international standards highlight the importance of professionalism, accountability and respect for due process rights in police relationships with young people. Studies have noted that people's attitudes towards the law and legal authorities are formed in 
childhood as part of the socialization process and have a lasting impact [14, 17; p.196].

Critically, negative contact with the police during adolescence may have a significant impact on lowering young people's attitudes towards them. This is exacerbated by the fact that young people, as users of public space, often experience involuntary contact with the police which they view as negatively adversarial in nature [17; p.198; 22; pp.76-79]. Hinds' study of the issue in New South Wales found that, consistent with research with adults, "perceptions of police use of procedural justice are the primary factor shaping young people's assessments of police legitimacy' [17; p.203]. In particular, children's normative beliefs that police use fair procedures in encounters with young people were the most significant influence in shaping their attitudes about police legitimacy. Hinds notes that police use of fair procedures entails giving young people an opportunity to have their say before making a decision, being treated in a neutral and consistent way, and being treated with dignity and respect [17; p.203].

In the Irish context, research into the leisure activities of young people living in disadvantaged communities has found that the young people's preferred activity is 'hanging around' on the streets with friends and that young people consider that there are insufficient public and private leisure amenities available to them in their areas [5]. This increases the chances that young people in these communities will interface with police in a negative way, with negative knock-on consequences for both parties. In fact, this is one of the findings of a small Dublin-based study into young people's experience of youth justice in their community where negative relations with the police was raised as their principal concern in this context. ${ }^{6}$

In summary, it is clear that international standards on youth justice place considerable emphasis on the importance of due process, training, professionalism and accountability with respect to police relationships with young people. They require that express and transparent limits be placed on the exercise of police discretion and that such decisions be subject to review. They require that children can access an independent complaints mechanism. International standards also advocate a range of responses to youth offending, including nonintervention, and stress the importance of adhering to due process values regardless of the approach taken. The next part of the paper considers the extent to which these values are

\footnotetext{
${ }^{6}$ This study ('Social integration of young people in contact with the youth justice system: a youth action research project') was undertaken by Dr Angela Veale and Dr Ursula Kilkelly, University College Cork supported by YAP Ireland, and funded by the Irish Research Council of the Humanities and Social Sciences. It is currently being prepared for publication. See also [22; pp.82-84].
} 
represented in the law and policy framework that governs the treatment of children by the police as part of the Garda Diversion Programme in Ireland.

\section{National Law and Policy}

\section{The Children Act 2001, as amended}

The Garda Diversion Programme, or the Juvenile Liaison Officer (JLO) Scheme as it was formerly known, has been in place since 1963. Initially set up in the Dublin Metropolitan Area, its purpose was to put in place a system for cautioning children who committed offences rather than having them dealt with by way of prosecution. According to the Scheme, the District Officer (Garda Superintendent) referred the child to a JLO, who then visited the child's home and dealt with the matter by way of caution, advice and supervision. Where appropriate, the JLO also provided support to the family. The aim was to prevent further offending and to divert the child away from a possible life of crime. The Scheme was launched nationwide in 1981 and in 1991, the Garda National Juvenile Office was established and given a co-ordinating and monitoring role. The maximum age for admission to the Scheme was also raised from sixteen to eighteen years [3; p.7].

It is a measure of support for the programme that it was given statutory recognition in Part 4 of the Children Act 2001. During its passage through the Dáil, the Minister for Justice, Equality and Law Reform described the Scheme as 'probably the single most important initiative in dealing with juvenile crime in the $20^{\text {th }}$ century'. ${ }^{7}$ The relevant sections of the Act were commenced quickly after the Act was passed [7]; suggesting that the legislation wrapped around the Programme, rather than fundamentally altering its design. At the same time, one of the advantages of putting the programme on a statutory basis was to ensure that it operated according to an agreed set of rules that were to be evenly and equally applied. Under the Act, therefore, the principal decision-making functions are vested in the Director of the National Juvenile Office, and the merits of having a streamlined and consistent decision-making process are clearly linked to the legitimacy of the Programme as a whole. Since the enactment of the 2001 Act, all children who come into contact with the police are now referred automatically to the Diversion Programme, although, as outlined below, not all are admitted.

\footnotetext{
${ }^{7}$ Dáil Debates, Vol 517, Col 33-34 (29 March 2000).
} 
The Garda Diversion Programme offers a child who has committed an offence an opportunity to be cautioned in lieu of prosecution. ${ }^{8}$ When a child first comes to the attention of An Garda Síochána he/she is usually referred to the local Juvenile Liaison Officer, who is a specially trained member of the Garda. If the child fulfils the eligibility criteria for admission to the Programme, ${ }^{9}$ he/she may be admitted to receive a caution, with (formal) or without (informal) supervision. Usually, the informal caution is issued in respect of minor or first offences and is administered by the local JLO at the child's home, in the presence of his/her parents. A formal caution is administered either by the local District Officer or the JLO and takes place at the Garda station in the presence of the child's parent or guardian. This caution may be restorative in nature if the victim of the child's offending behaviour is present. In such cases the objective is to 'confront the child with the consequences of his/her offending' 'in a low key atmosphere'. ${ }^{10}$ When the victim attends, there must be a general discussion among those present about the child's criminal behaviour and the Garda administering the caution may invite the child to apologise and offer some form of compensation to the victim. In this way, the intervention may operate as a mini-conference where a full restorative conference is neither justified nor required.

The formal caution is normally accompanied by supervision meaning that the child will be monitored or mentored in the community by a JLO for a period of 12 months [6; s.27]. The level of supervision required, which can also be varied by the Director, is decided by the JLO, who must take into account the seriousness of the criminal behaviour, the level of support to and control of the child by his/her parents or guardian, and the likelihood of the child committing further offences $[6 ;$ s.28(1) \& (2)].

The Children Act 2001 introduced a conference into the Diversion Programme, in a 'major innovation in Irish criminal law' [24; p.65]. In respect of a child who is being supervised, the JLO may convene a conference in order to bring together, on a voluntary basis, the child, his/her family and others to establish the reasons for the child's criminal behaviour and discuss how the family can help the child to avoid re-offending [6; ss.29 \& 30-39]. The JLO

\footnotetext{
${ }^{8}$ A child shall not be prosecuted for the criminal behaviour, or any related behaviour, in respect of which he or she has been admitted to the Programme [6; s.49].

${ }^{9}$ The child must be over the age of criminal responsibility and under 18 years, have accepted responsibility for the offence committed, and have consented to being cautioned under the programme.

${ }^{10}$ As explained by the Minister for Justice, Equality and Law Reform in his introductory speech at the Second Stage, Dáil Debates, Vol 517, Col 36 (29 March 2000).
} 
is responsible for organising the conference and must explain the procedures to the child and his/her guardian and ascertain the wishes of the child and the victim with regard to the conference. The JLO also has a particular function to mediate between the child and the victim. JLOs receive special mediation training for this purpose. ${ }^{11}$

One of the principal functions of the conference is to provide a forum within which the child and his/her parents can draw up an action plan with the assistance of others (e.g. the child's teacher, social worker or youth worker) to try to prevent the child from re-offending. The plan may provide for any course of action that would be in the best interests of the child or would make the child more aware of the consequences of his/her criminal behaviour, including requiring the child to make reparation to the victim, participate in sporting or educational activity, stay at home at certain times and away from certain places or people [6; s.39(3)]. While there are no sanctions for non-compliance with the action plan, one or more people may monitor the child's compliance with it and the conference may be reconvened to review compliance. The action plan thus takes the form of a contract between the child and those present at the conference and, although it is not legally enforceable, the consent of the parties is required in most circumstances. The seriousness of what is at stake is reinforced by the requirement that the child must sign the action plan, which must be written in plain language that he/she can understand [6; s.39(4) \& (5)].

The Criminal Justice Act 2006 made a number of changes to the Garda Diversion Programme. ${ }^{12}$ In the context of this paper, the most relevant amendment concerns the longerterm effects of a young person's involvement in the Programme. As a general rule, a young person cannot be prosecuted in respect of the offences that led to his/her involvement in the Programme. ${ }^{13}$ Related to this, the original version of section 48 of the 2001 Act prohibited the admissibility in subsequent proceedings of certain evidence relating to the child's involvement in the Programme. In particular, this excluded as inadmissible evidence in

\footnotetext{
${ }^{11}$ In October 2007 a new training programme for JLOs was introduced, consisting of five modules delivered over an 18 month period. This includes 80 hours mediation training, certified by the Mediation Institute Ireland [4; p.26]. The Garda Youth and Children Strategy makes a commitment to ensuring that all new JLOs receive this training further [2; p.13].

${ }^{12}$ Section 123 of the 2006 Act amended s 18 of the 2001 Act to allow for children over 10 years (and thus under the ordinary age of criminal responsibility) who have been involved in anti-social behaviour to be admitted to the Programme. These amendments have been criticised as an unnecessary expansion of the criminal justice system. See [9; paras.70-71].

${ }_{13}$ A similar rule now exists with regard to involvement in anti-social behaviour and the application for a Behaviour Order.
} 
respect of: (a) any acceptance by a child of responsibility for criminal or anti-social behaviour in respect of which the child has been admitted to the Programme; (b) that behaviour, or (c) the child's involvement in the Programme. However, this version was amended by section 126 of the 2006 Act which provides that such evidence can be put before the court by the Prosecution where a court is considering the sentence (if any) to be imposed in respect of an offence committed by a child after the child's admission to the Programme [20]. Admittedly this can only affect those who re-offend and are prosecuted but nonetheless it is a substantial change to the terms on which young people enter the Diversion Programme. In particular, they can no longer be assured, as they would previously have been, that their participation in the Programme will not be taken into account in any subsequent criminal proceedings. Although it is too early to see the implications of this change, it presents JLOs with a dilemma when trying to encourage young people to get involved in the Programme. On the one hand, diversion will often be considered to be in the child's interests and may be preferable to prosecution; on the other hand, it is not without conditions which may have negative consequences for the child who re-offends. In this regard, it has changed the advice that JLOs and the child's legal representative must give to those considering diversion as an alternative to prosecution. It has also changed fundamentally the basis on which the Programme operates. This issue will be revisited later. Attention will turn now to the policy context in which the policing of young people takes place.

\section{An Garda Síochána Youth and Children Strategy}

Following on from the National Youth Justice Strategy adopted by the Irish Youth Justice Service in 2008[15], the Garda Youth and Children Strategy 2009-2011 was published in 2009 [2]. The Garda Strategy is informed by a mission statement which makes a commitment inter alia to be 'particularly sensitive to the needs and rights of children' and to endeavour to maintain the highest recognized international standards of behavior and best practices when dealing with children and young people' [2; p.5]. The Strategy has three high level goals. The second of these, which is most relevant here, is the provision of a policing service to children in conflict with the law. The Strategy document sets out numerous organizational commitments that extend beyond the more general policing values of personal protection, community commitment and state security $[1 ; \mathrm{p} .9] .{ }^{14}$ In particular, the Strategy makes a

\footnotetext{
${ }^{14}$ This lists a commitment to values including public accountability, disciplined professionalism, partnership with the community and respect for human rights.
} 
commitment to ensuring the provisions of the United Nations Convention on the Rights of the Child are upheld in police interaction with children; to ensuring the highest level of international best practice is adhered to when dealing with children in conflict with the law (noting the Beijing Rules in particular); and to a multi-agency approach to the needs of children and young people [2; p.5]. This awareness of and commitment to Ireland's international legal obligations and best practice elsewhere is welcome. ${ }^{15}$ Although implicit in the Strategy, more explicit reference might have been made to the specific requirements of these obligations in terms of ensuring adherence to the values of transparency, accountability and respect for due process in all Garda relations with young people. At the same time, it is important that the Strategy's broad principles are followed through with more precise commitments to raising awareness on the rights of children, to training on the requirements of international conventions on child custody and to identifying and rewarding best practices with dealing with young people. ${ }^{16}$ In terms of achieving its objectives, the Strategy identifies a number of precise and measureable commitments to improve the effectiveness and efficiency of police interventions with young people. So, for example, in addition to increasing the resources to the Diversion Programme and promoting greater understanding of the Programme among children and their families, the Strategy commits to ensuring that children not deemed suitable for Diversion have their cases processed within one month of being received by the National Juvenile Office [2; p.11]. Commitments are also made to update and standardize procedures relating to the Diversion Programme and to develop new induction and specialized training for Juvenile Liaison Officers [2; p.15].

Overall, the Strategy is to be welcomed as a clear attempt to improve practice in the Diversion Programme in line with international standards. Although it indicates a clear commitment to ensure greater adherence to values of due process, and advocates many measures that may enhance the legitimacy of the police among young people, it arguably falls short in respect of measures necessary to ensure greater accountability. For example, greater consideration might have been given to establishing an independent review mechanism to ensure that young people have recourse to an appeal in respect of the decision whether or not to admit them to the Programme and if so, the type of measure to administer. An explicit link with the complaints mechanism under the Garda Síochána Ombudsman Commission (GSOC)

\footnotetext{
${ }^{15}$ This reflects the recommendations in [10; para.28]. By contrast, this reference is conspicuously absent from the National Youth Justice Strategy [18].

${ }^{16}$ These specific actions fall under High Level Goal 1, providing a policing service to all children [2; $\mathrm{p}$ 9].
} 
might also have been made, including a commitment to raise awareness among young people as to how they can avail of the remedy that GSOC offers. More generally, it would appear that children and young people were not engaged in the development of the Strategy and although several actions identify the need to engage more actively with children and young people, it would have been worthwhile to involve children directly in both the drafting, the review and the implementation of the Strategy. ${ }^{17}$ Furthermore, there is a lack of provision for implementation and oversight structures in that the Strategy does not make any commitment to its review or evaluation, independent or otherwise.

\section{Implementation of the Programme}

In 2009, the latest year for which information is available, the Report indicates that 18,519 children were referred to the National Juvenile Office [4; p.9]. ${ }^{18}$ This involved a drop in the number of children referred - 21,412 children were referred in 2008 - and is closer to the 17,567 children referred in 2005 for example [4; p.10]. This is the first significant drop in the number of children referred for many years and although its causes are unknown it is likely that 2010 will see an increase again as the computerisation of the referral process allows more young people to be referred. In any event, the changing trends should be kept under careful review.

In 2009, there were 14,047 children cautioned under the Programme - a drop for the second subsequent year $[4 ; \mathrm{p} .12]^{19}$ although the number of children deemed suitable for formal and informal cautions has remained relatively constant. In 2009, a formal caution was considered appropriate in $22 \%$ of the children referred (an increase from $18 \%$ in 2008), while an informal caution was deemed suitable in $54 \%$ of referrals, again an increase on previous years [ $4 ; \mathrm{p} .12]$. This latter figure drops to $46 \%$ in respect of the overall number of children referred, meaning that for almost half of the children referred to the Programme the outcome was a caution without supervision, ie the least invasive measure possible [4; p.8]. This number is falling, however.

\footnotetext{
${ }^{17}$ The same point can be made about the National Youth Justice Strategy where the failure to involve children in the drafting and implementation of the Strategy is even more regrettable especially given that the National Children's Strategy makes listening to children one of its three high level goals. See [25]. See also [4].

${ }^{18}$ These children were referred for 23,952 offences [4; p.8].

${ }^{19}$ This is down from 15,754 in 2008 although this is still considerably higher than the 12,799 children cautioned in 2004.
} 
Against this backdrop, the percentage of children deemed suitable for inclusion $-76 \%$ in 2009 - has been relatively stable over the last five years $[4 ; \mathrm{p} .12] .{ }^{20}$ The number deemed unsuitable stands at $16 \%^{21}$ meaning that in 2009, 2,966 children referred for admission to the Programme were rejected [4; p.15]. In 2009, a further $6 \%$ of children referred were found to require 'no further action' and this would appear to represent those cases where the offence involved was very minor or where for other circumstances the child's involvement in the Programme would not be appropriate [4; p.8]. According to the 2009 Report, a child will be considered unsuitable if he/she does not accept responsibility for the behaviour, if it would not be in the interests of society to caution the child and the child is offending persistently. The first criterion is a requirement for admission, in the sense that a child who does not accept responsibility cannot be admitted. Given the figure for 'no further action', the second factor would appear to relate to those children for whom admission to the Programme would be inappropriate on the basis of the serious nature of their offending. This would appear to overlap with the third criterion which relates to those cases for whom prosecution is preferable. As the Report indicates, these cases are then referred back to local Garda management who decide, following consultation with the Director of Public Prosecutions where appropriate, if prosecution will be taken [4; p.15]. In this regard, while the explanation provided by the Report is useful (and repeated year on year), much more information is needed to allow a fuller understanding of why these young people are rejected from the Programme. Moreover, the significance of the fact that almost one quarter of those referred are not admitted is also worthy of careful scrutiny, not least to ensure that the best use is being made of Garda resources in this context. Greater transparency would be aided by the Director making public more detailed reasoning for the decisions made although it is to be presumed that the young people themselves are given those reasons directly. It might also be useful to reflect on whether some refinement of the process could avoid referring to the Programme those children who are simply ineligible. In this regard, s 47 of the Children Act 2001 allows the Minister to make regulations inter alia to prescribe any criminal behaviour of a serious nature in respect of which admission to the Programme shall be excluded. Such regulations could more tightly circumscribe the discretion currently exercised here and could also bring the operation of the Programme closer into line with international standards.

\footnotetext{
${ }^{20}$ In 2008, this figure was $75 \%$, a drop from $76 \%$ in both 2007 and 2006 [4; p.12].

${ }^{21}$ This is up $2 \%$ from a low of $14.1 \%$ in 2006 . The rate in 2004 was $15.4 \%$. Ibid. When considered as a percentage of case (rather than child) referrals this number rises to $25 \%$ in 2008 .
} 
The nature of the offending for which children are referred to the Programme has not changed significantly over the years. The picture in 2009 is dominated, as in previous years, by alcohol related offences (which comprised $17.6 \%$ in 2009), road traffic offences (13\%) and theft at $16.6 \%$ [4; p.16]. Other less common offences include criminal damage (10.6\%), public order offences (9.5\%), assault and drugs possession (at $4.4 \%$ each) and other traffic offences at $13 \%$. The more detailed breakdown of offences sheds further light on the type of offences for which young people are referred. When the category of alcohol related offences is broken down, for example, the number of referrals $(4,252)$ divides into one third: 'purchase, possession or consumption of alcohol' (1,144 incidents) and two thirds: 'intoxication in a public place' (3,079 incidents). When public order offences are broken down, abusive and threatening behaviour $(1,435)$ and failing to comply with Garda direction (528) are the most significant categories. The main categories of road traffic offences are: no insurance (702), no seatbelt (226), speeding (460) and no road tax (336) [4; p.18]. Of what might be considered more serious offences involving violence, 392 incidents of serious assault were referred. Twelve of these were for assault causing serious bodily harm and 2 were for murder [4; p.19]. Sexual offences were also referred, with 40 referrals for sexual assault and 17 for rape [4; p.19].

A number of issues arise. The first is the fact that very serious offences such as murder and rape can be referred at all. It does not follow, however, that these offences are dealt with through the Programme. In practice, the offenders are refused and admission and dealt with through the mainstream criminal process. Nevertheless, the appropriateness of admitting sexual offenders to the Programme must be addressed. While the offences in question vary in seriousness, and admission may well be in an individual child's interests, the capacity of JLOs to deal with such offending and monitor the child concerned in the community suggests that this needs to be undertaken with some caution. At the other end of the scale is the treatment of alcohol. While it is obvious that alcohol is a significant driver in other youth crime such as public order, theft and criminal damage offences, it is arguable that these cases can be separated from those in which acquisition and consumption of alcohol is the issue; i.e. those cases where young people have stolen or otherwise obtained alcohol through false means and been apprehended for being intoxicated in a public place. The seriousness of this problem is not underestimated, but it is difficult to separate it from the largely endemic nature of alcoholism in Irish society [21; pp.414-421]. In order to promote a better understanding of 
the nature of this type of offending and the role of the Diversion Programme in this area, an in-depth study of the alcohol-related crime for which children are admitted into the Programme should be undertaken. Moreover, in light of the fact that only $3 \%$ of children referred to the Programme are not admitted and are referred instead to the Health Service Executive (HSE), particular consideration might be given to the role of the HSE in this area and how it might be expanded.

These statistics raise important issues about the scope of the Diversion Programme and its application. On the one hand, the figures highlight the need to maximise the precious resources of the Programme (notably the time of specially trained JLOs) to allow investment in those children who stand to benefit most from Garda intervention. This would require a response to child offending that views offending along a sliding scale where children involved in low level offending receive no intervention, the more serious are considered appropriate for referral and those involved in persistent and/or serious offending are referred for prosecution. The application of such a system might mean that all children would not continue to be referred to the Programme regardless of the nature of their offending or their circumstances. Downsides to this approach would include the risk of discriminating between children on the basis of discretion loosely exercised. However, this could be addressed by ensuring that each category is strictly defined, and, additionally, by providing a procedure for independent overview of the Programmer's operation and the discretion involved in its administration. This might be achieved either by providing an independent review or appeal mechanism for children affected adversely by particular decisions, or alternatively through the means of a regular, independent spot-check to ensure consistency in the decision-making process. Possible options are available in the form of the Garda Síochána Ombudsman Commission or the Ombudsman for Children both of whom are familiar with these processes.

In any event, it is apparent that there is a need to ensure constant vigilance in relation to the best use of the Programme. The fact that the vast majority of children admitted receive an informal caution, and thus no other intervention, raises questions as to whether the associated formality of admission to the Programme is a proportionate response to their behaviour. On the other hand, it is apparent that the more intensive interventions are being reserved for a small number of more serious cases. This is welcome but it should be accompanied, perhaps, by a commitment to focus on those cases in the Programme as a whole. 


\section{Due Process Concerns}

Also related to the legitimacy of the Programme are concerns about its compatibility with traditional due process values and rights. First, as already outlined, in order for a child to be considered for admission, he/she must accept responsibility for the alleged offence and agree to be cautioned and, where appropriate, supervised by a Juvenile Liaison Officer. The child is thus not under any compulsion to subject him/herself to the Programme and what it involves: he/she retains a veto in that respect [31; p.7]. Despite the different language used, Walsh considers that accepting responsibility is 'equivalent to a guilty plea' [31; p.6]. In acknowledgement of that fact, the Act makes specific provision for the child's right to receive legal advice before making a decision in this regard. According to section 23 of the Act, the child seeking admission to the Programme must accept responsibility for his/her

criminal behaviour, "having had a reasonable opportunity to consult with his or her parents or guardian and obtained any legal advice sought by or on behalf of him or her'. The importance of the legal advice relates, more importantly perhaps, to what is at stake for the young person admitted to the Programme. As the terms of the 2001 Act make clear, it will involve a caution and may also involve supervision for up to 12 months by a Juvenile Liaison Officer. In certain circumstances, participation in a family conference will be required and what is proposed in the action plan, drawn up in this process, can be far reaching in nature. The terms of section 39 of the Act provide that an action plan may include provision for 'one or more of the following matters': an apology to the victim; financial or other reparation to the victim; participation by the child in an appropriate recreational activity; attendance of the child at school or work; participation in an appropriate training programme or educational course; the child staying at home at certain times; the child staying away from certain people; taking initiatives within the child's family and community that might prevent the child from further offending, and finally, 'any other matters that in the opinion of those present at the conference 'would be in the child's best interests or would make the child more aware of the consequences of his/her criminal behaviour'. By any analysis, these interventions can be extensive and prolonged in their impact on the child's autonomy, behaviour and freedom [31; p.6]. Given that this may involve penalties that go well beyond those ordered by a Court 
should the child prefer prosecution, it is vital that the due process right to legal advice apply at this initial stage at least. ${ }^{22}$

It is clear that, as Walsh remarks, the 'due process protections diminish' once the child has admitted responsibility for his/her behaviour [31; p.7]. Once the child has accepted responsibility, there is no further right to either legal representation or advice regarding any aspect of the child's treatment in the Programme. It may be argued that the nature of the diversion process is sufficiently different to the trial process to justify the child waiving his/her due process rights (along with his/her right to face trial) in that the child avoids both prosecution and conviction should he accept the conditions attached to the Diversion Programme. But, as is clear from Article 40(3) of the Convention on the Rights of the Child, diversionary approaches must only be pursued where the rights of children are fully protected $[19 ;$ p.75]. Thus while some degree of informality may be permitted in the context of diverting a child from the formal criminal justice system, the importance of due process rights should never be undermined. These rights are important not just to safeguard the interests of children in the Diversion Programme, but to enhance their faith in the fairness and legitimacy of its process [19; pp.75-76].

The importance of legal advice for the child is further enhanced by the changes effected by the Criminal Justice Act 2006, which allow evidence as to the child's involvement in the Programme to be admitted in subsequent proceedings at the sentencing stage [20]. What this means is that evidence of the child's involvement in the Programme ${ }^{23}$ will be taken into account as part of the sentencing process, notwithstanding that the child has not been charged, prosecuted or convicted in respect of the offence for which he was admitted to the Programme. In addition to altering fundamentally the basis on which the child now enters the Programme - which previously offered diversion and a clear slate in return for agreeing to be cautioned and supervised - this also brings the importance of the legal advice obtained by the child prior to admission into even sharper relief. It is possible of course that the child who reoffends will have had an exemplary experience in the Diversion Programme and so has nothing to fear by the reversal of the terms of section 48 . However, such scenario is likely to

\footnotetext{
${ }^{22}$ Indeed, Griffin has recommended that legal advice be mandatory at this stage [16; p.5]. See also Kilkelly [19; p.76].

${ }^{23}$ This relates to the offences which gave rise to such involvement, the accepted responsibility of the young person for this behaviour and the child's behaviour in the Programme.
} 
be rarer than the more common one where the child before the court, having re-offended, has had a less than successful experience. In any event, it is important that those providing legal advice to children prior to admission to the Programme bring this specific condition to their attention. More generally, the condition appears to bring the Programme into conflict with the international standards - which require that the child who chooses the alternative to prosecution does not suffer any legal disadvantage as a result - and the original provision should be reinstated before the amended one is the subject of a legal challenge. ${ }^{24}$

A final issue of concern here is the so-called monopolisation of the Diversion Programme by the Garda Síochána. Although it is welcome that the Programme enjoys a statutory basis and operates according to the framework set out in Part 4 of the Children Act 2001 as amended, it is indisputable that the Garda Síochána has complete control over all stages of its management, administration and review. According to the Act, the Commissioner retains general control over the Programme which is managed by an individual member acting as the Director. The Director has substantial discretionary powers including whether to admit the child in the first instance (s 24), whether the child should receive a formal or an informal caution (s 25), whether to hold a conference (s 31) and varying the period and level of supervision the child receives (s 42). The Director also appoints the convenor and chair of the conference, should one be held, and this person (usually the same person in the form of a JLO or ordinary Garda) enjoys 'extensive discretion over the composition, timing and location of the conference, the procedure to be followed and the manner in which it conducts its business' $[31 ;$ pp.7-8]. The outcome of the conference in the form of the action plan is not subjected to any external approval ${ }^{25}$ and although it may be drawn up by the child, his/her family and others with an interest in the child it is clear that the process takes place almost exclusively within the remit of the Garda Síochána. As Walsh notes, "what emerges... is a process that is almost wholly under the control of gardai acting in an executive capacity as opposed to judges or other officials acting in a judicial capacity [31; p.8]. The child is in an especially vulnerable position throughout and although his/her parents will normally be present, research shows that young parents and relatives are 'probably the least well qualified to give advice on how the interest of young persons may be best advanced in the process' $[26$;

\footnotetext{
${ }^{24}$ See the criticism of the Committee on the Rights of the Child on this point [9; paras.70-71].

${ }^{25}$ This can be contrasted with the Probation-led family conference [6; pt.8].
} 
p.237]. ${ }^{26}$ There is also no recourse, apart from the possibility of a complaint to the Garda Síochána Ombudsman Commission, to a remedy for the child alleging unfair or disproportionate treatment either in the Programme or because he/she was denied admission. Walsh's conclusion is that the diversion process reflects 'a major departure from due process norms' and notwithstanding that the child may benefit from a 'welfare trade-off' of avoiding prosecution before the Children Court, this is insufficient to ensure compliance with international children's rights obligations, which make clear that there can be no such trade off. They similarly require a right of appeal to decisions taken in the Diversion Programme. It is certainly clear that failure to provide any such remedy is problematic in the Irish context notwithstanding the Programme's success.

As to how these issues might be addressed, there are two obvious areas for attention. The first is to improve overall transparency in the Programme by requiring the National Juvenile Office to publish reasons for its (or rather the Director's) decisions. This would help to clarify the basis on which children are not admitted to the Programme, and the reasons underpinning the choice of sanction to be applied (eg formal, informal caution, supervision, conference) and putting more detailed and specific data into the public domain would certainly improve confidence in the fair operation of the Programme. The need for rigorous, independent research into the operation of the Programme is centrally linked to its legitimacy and should become an urgent priority. The second recommendation is to give consideration to the stages of the process at which civilians are involved formally in the Programme. The obvious place to start is to increase the independent or civilian representation on the Committee that monitors the Diversion Programme. This Committee is not privy to any sensitive information and there is no reason why a majority of its members could not be drawn from civil society and include representatives from youth groups in particular. Similarly, very serious consideration should be given to assigning specific roles within the Programme to those outside the police force, with particular consideration being given to establishing an appropriate adult scheme to ensure that young people enjoy independent advocacy and legal advice at appropriate points throughout the Programme. While these elements may undermine one of the Programme's significant features, namely its informality, the consequences for the young person involved in the Programme are now so serious as to make

\footnotetext{
${ }^{26}$ This research concerned the role of the appropriate adult, and so a formal advice-giving role but, it is submitted, they are equally relevant here.
} 
them unavoidable. In particular, the increased scope of the Programme, the onerous and disproportionate measures that may be imposed on the child by virtue of his/her involvement in the Programme and the chances that those who re-offend will find their involvement in the Programme 'used against them' in any future sentencing make it clear that a much greater adherence to due process values is now urgently required. Given that their treatment in the Diversion Programme is likely to have a serious impact on the young person's relationship with the police, it is even more vital that fairness and respect become the principal guiding values of the Diversion Programme both in substance and in appearance.

\section{Monitoring and Complaints}

Section 44 of the Children Act 2001 provides for a Committee to Monitor the Effectiveness of the Diversion Programme. The annual reports of this Committee provide an important perspective on the nature and scale of juvenile crime, together with a useful summary of the operation of the Programme in response. Trends emerge when the reports are considered year-on-year. Although the Committee has two lay members, it is chaired by an Assistant Commissioner and contains two further Garda members. Accordingly, it could not be said (nor does it profess) to engage in any independent monitoring of the Programme. The Programme is thus not subject to any independent monitoring or review, either in general or in case-specific terms. Although children aggrieved at their treatment by the police can complain to the Garda Síochána Ombudsman Commission (GSOC), the importance of this area of police activity demands that the Programme subscribe to higher standards of accountability, incorporating a system of independent review and monitoring [12].

In the absence of any review or appeal mechanism within the Diversion Programme itself, there is a clear need to make an independent, statutory police complaints facility available specifically for those under 18 years of age. The GSOC offers two types of remedy to young people in respect of their treatment by the police. Under section 102(1) of the Garda Síochána Act 2005, the Garda Commissioner can refer to the Commission any matters that appear to indicate that the conduct of a member of the Garda Síochána may have resulted in the death of or serious harm to a person. The Commission must then ensure that matter is investigated. In $2009,10.9 \%$ of such referrals concerned those under 18 years. In practice, however, the primary remedy is that anyone, regardless of age, can submit a complaint to GSOC alleging misbehaviour, the commission of a criminal offence or breach of discipline by a member of 
the Garda Síochána. Under section 3 of the 2005 Act a complaint can be made by the person directly affected or by someone who makes that complaint on their behalf. This latter facility is important from the perspective of a child who might need support to access the complaints process. Although the Act sets out detailed rules for the handling of such complaints, it makes no provision for ensuring that the procedure is age-appropriate or fully accessible to those under 18 years. Complaints can be made directly to GSOC by 'phone or in person but a child who seeks to complain about his/her treatment at the hands of a police officer is unlikely to take such a step given the fear of repercussions. In this regard, there is little to reassure young people that their complaint will not have adverse consequences for them in their community. The relevant complaint form, which has not been adapted for those under 18 years, does not offer any support for those who might have such fears.

It is not surprising therefore that such a small proportion of the Commission's work in this area concerns the complaints submitted by or on behalf of young people. In 2007, these amounted to $1.6 \%$ of complaints, and although this increased to $3.5 \%$ in 2008 it fell again in 2009 to $2.5 \% .^{27}$ The majority of complaints made by young people since 2007 have been submitted by those over 15 years and in terms of the substance of complaints, the majority concerned abuse of authority (27\%), discourtesy (13.5\%) and non-fatal offences $(40.5 \%){ }^{28}$ Importantly, in terms of the location of the source of the complaint, the majority (42.1\%) took place in a public place. This is consistent with the view that public places represent a flashpoint for young people and the police. Thirty one percent of complaints related to treatment in Garda custody. ${ }^{29}$ To date, none of the complaints appear to have resulted in a positive outcome for the child complainant. No breach was identified in $39.6 \%$ of cases with further investigation not considered necessary in $35.6 \% .{ }^{30}$ Given the level of contact that young people have with the police, both formally and informally, it seems reasonable to suspect that these figures reflect a general lack of awareness among young people about the GSOC remedy, concerns about the inaccessibility of the process to young people, and/or their lack of confidence that the procedure will effectively address their complaints without having negative consequences for them. This is supported to some extent by Conway's finding that

\footnotetext{
${ }^{27}$ This information - concerning complaints made between May 2007 and February 2010 - was made available via personal correspondence with GSOC's Communication and Research Section, 31 $1^{\text {st }}$ March 2010.

${ }^{28}$ Ibid.

${ }^{29}$ Ibid.

${ }^{30}$ Ibid.
} 
young people feature more prominently in s 102 investigations, where serious harm or death has occurred and which do not require a complaint from the victim to be initiated [12: p.124]. More detailed analysis of the data should be undertaken with a view to establishing the veracity of these concerns.

\section{Conclusion}

The Garda Diversion Programme remains the most coherent and effective response to youth offending in Ireland. Through a series of informal and formal measures administered by specially trained police officers, the Programme attempts to intervene in children's lives in a timely manner to prevent an initial involvement in offending behaviour developing into more persistent and serious criminal activity. Its placement on a statutory basis in the Children Act 2001 is a welcome development which has streamlined the decision-making process around admission to and implementation of the Programme. The adoption of the Child and Youth Strategy is a welcome focus on the rights of young people in the Programme and reflects a welcome commitment to international standards. However, efforts must be made to engage with young people in its implementation and to establish structures to ensure it is subject to independent review.

Against the backdrop of international standards and their emphasis on due process and accountability, questions remain about the extent of the discretion currently being exercised during different stages of the decision-making process in the Diversion Programme, and the transparency that accompanies the decisions made. The absence of any review or appeal mechanism with respect to individual decisions, and of any independent monitoring of the Programme generally, mean that the Programme currently falls short of international standards. And, given the implications of these decisions for children's lives, and for their faith in the process to which they are encouraged to subject themselves through its voluntary nature, serious consideration should be given to taking a number of remedial measures. First, more information should be made publicly available about the reasons for the decisions taken with respect to admission to the Programme and the nature of the intervention chosen. Young people should have the opportunity to request a review of such decisions within a timely manner. This might be carried out by the GSOC or the Ombudsman for Children. Any refusal should be accompanied by a right of appeal. Second, in addition to the incorporation of a review mechanism, consideration should be given to putting in place independent monitoring 
structures to spot-check decisions made within the Programme and to achieve independent review of the Programme's operation as a whole. Finally, linkages between the Diversion Programme and the GSOC complaints mechanism should be developed to ensure that young people involved with the police are made fully aware of the remedy available, and can access an age-appropriate process designed to protect their rights and interests. These, and other steps outlined above, are critical to the legitimacy of the Diversion Programme and to the positive relationship that it can help build between young people and the police, with all the attendant consequences that has for young people, and for society as a whole.

1. An Garda Síochána. (2007). Corporate Strategy 2007-2009: A Time for Change Garda. Dublin: An Garda Síochána.

2. An Garda Siochána. (2009). Youth and Children Strategy 2009-2011. Dublin: An Garda Síochána.

3. Annual Report of the Committee appointed to monitor the effectiveness of the Diversion Programme. (2003). Dublin: Department of Justice, Equality and Law Reform.

4. Annual Report of the Committee Appointed to Monitor the Effectiveness of the Diversion Programme. (2009). Dublin: Department of Justice, Equality and Law Reform.

5. Byrne, T., Nixon, E., Mayock, P., \& Whyte, J. (2006). The Free Time and Leisure Needs of Young People living in Disadvantaged Communities. Dublin: Combat Poverty Agency Working Paper Series 06/02. Available at www.combatpoverty.ie (20 February 2010).

6. Children Act, 2001.

7. Children Act, 2001 (Commencement) Order, 2002.

8. Committee on the Rights of the Child. (2003). General Measures of Implementation General Comment No 5 CRC/C/GC/5 9.

9. Committee on the Rights of the Child. (2006). Concluding Observations: Ireland, CRC/C/IRL/CO2. Available at www.ohchr.org (20 February 2010).

10. Committee on the Rights of the Child. (2007). Children's Rights in Juvenile Justice, General Comment No 10CRC/C/GC/10.

11. Committee on the Rights of the Child. (2009). The Right of the Child to be Heard. General Comment No 12CRC/C/GC/12. 
12. Conway, V. (2009). A Sheep in Wolf's Clothing? Evaluating the Impact of the Garda Síochána Ombudsman Commission. Irish Jurist, 43, 109-130.

13. Council of Europe. (2008). Recommendation CM/Rec (2008)11 of the Committee of Ministers to member states on the European Rules for juvenile offenders subject to sanctions and measures. Strasbourg: Council of Europe.

14. Dennis, J., Easton, D., \& Easton, S. (2007). Children in the political system: Origins of Political Legitimacy. New York: McGraw-Hill.

15. Goldson, B. (2000). Wither Diversion? Interventionism and the New Youth Justice. In Goldson, B. (ed). The New Youth Justice. Lyme Regis: Russel House Publishing.

16. Griffin, D. (2005). Restorative Justice: A Real Alternative? Irish Criminal Law Journal, 15(4), 2.

17. Hinds, L. (2007). Building police-youth relationships: the importance of procedural justice. Youth Justice, 195-209.

18. Irish Youth Justice Service. (2008). The National Youth Justice Strategy 2008-2010. Dublin: Stationery Office.

19. Kilkelly, U. (2006). Youth Justice in Ireland. Dublin: Irish Academic Press.

20. Kilkelly, U. (2007). Reform of Youth Justice in Ireland: The "New" Children Act 2001 Part 2. Irish Criminal Law Journal, 17(1), 2.

21. Kilkelly, U. (2008). Children's Rights in Ireland: Law, Policy and Practice. Dublin: Bloomsbury Publishing.

22. McAllister, S., Scraton, P., \& Haydon, D. (2009). Childhood in Transition Experiencing Marginalisation and Conflict in Northern Ireland. Belfast: Queen's University.

23. McAra, L., \& McVie, S. (2007). Youth Justice? The Impact of System Contact on Patterns of Desistance from Offending. European Journal of Criminology, 4(3), 315345

24. McDermott, P.A. \& Robinson, T. (2003). Children Act 2001. Dublin: Thomson Round Hall.

25. National Children's Office. (2000). Our Children their Lives: National Children's Strategy. Dublin: Department of Health and Children.

26. Quinn, K. \& Jackson, J. (2007). Of Rights and Roles. Police Interviews with Young Suspects in Northern Ireland. British Journal of Criminology, 47, 234-25.

27. United Nations Convention on the Rights of the Child 1989. 
28. United Nations General Assembly. (1985). The Standard Minimum Rules on the Administration of Juvenile Justice (the Beijing Rules), Adopted by General Assembly resolution 40/33 of 29 November 1985. New York: United Nations.

29. United Nations General Assembly. (1990). Guidelines for the Prevention of Juvenile Delinquency (the Riyadh Guidelines). Adopted and proclaimed by General Assembly Resolution 45/112 of 14 December 1990. New York: United Nations.

30. Walsh, D.P.J. (2005). Juvenile Justice. Dublin: Round Hall Press.

31. Walsh, DP.J. (2008). Balancing Due Process Values with Welfare Objectives in Juvenile Justice Procedure: Some Strengths and Weaknesses in the Irish Approach. Youth Studies Ireland. 3,2 (2008).

32. Waters, I. (2007). The Policing of Young Offenders British Journal of Criminology, 47, 635-654. 